\title{
Human and Bovine Milk: Comparison of Ganglioside Composition and Enterotoxin- Inhibitory Activity
}

\author{
ASTRID LÆGREID, ANNE-BRIT KOLST $\varnothing$ OTNÆSS, AND JAN FUGLESANG \\ University of Oslo, Department of Biology, Division of Zoology [A.L., A-B.K.O.] and National Institute of Public \\ Health [A.L., A-B.K.O., J.F.], Oslo, Norway
}

\begin{abstract}
Milk gangliosides inhibit Vibrio cholerae enterotoxin and Escherichia coli heat-labile enterotoxin. Human milk gangliosides showed considerably higher enterotoxin-inhibitory activity compared to bovine and formula milk gangliosides as measured in vitro by enzymelinked immunosorbent assay and in vivo in rabbit small bowel loops. While gangliosides from less than $1 \mathrm{ml}$ human milk inhibited $0.1 \mu \mathrm{g}$ choleratoxin in vitro and in vivo, five to 10 times higher amounts of bovine milk gangliosides were necessary to achieve similar results. Analysis of the ganglioside composition in human, bovine, and bovine milkbased formula milk showed that the ganglioside patterns in human and bovine milk differed markedly. The ganglioside patterns of bovine milk and formula milk appeared identical. In human or bovine milk, the total amount of gangliosides was $11 \mathrm{mg} /$ liter compared to $6 \mathrm{mg} / \mathrm{liter}$ in formula milk. The predominating ganglioside in human milk, monosialoganglioside 3 (74\% of total gangliosides), was only a minor component $(3 \%)$ of bovine milk gangliosides. Disialoganglioside 3 represented $80 \%$ of bovine milk gangliosides compared to $25 \%$ of the human milk gangliosides. Trace amounts of monosialoganglioside 1 were detected in human, as well as in bovine, milk by a sensitive high performance thin-layer chromatography immunoassay. The monosialoganglioside 1 content in human milk was 10 times higher than in bovine milk. We conclude that the higher nonimmunoglobulin enterotoxin-inhibitory activity in human milk compared to bovine milk is associated with the differences in the ganglioside fraction. (Pediatr Res 20: 416-421, 1986)
\end{abstract}

\section{Abbreviations}

bmG, bovine milk ganglioside

CT, cholera toxin

ELISA, enzyme-linked immunosorbent assay

GM1, monosialoganglioside 1

GM2, monosialoganglioside 2

GM3, monosialoganglioside 3

GD1a, disialoganglioside 1a

GD3, disialoganglioside 3

GT1b, trisialoganglioside $1 \mathrm{~b}$

hmG, human milk ganglioside

Received June 12, 1985; accepted January 2, 1986

Address for correspondence Dr. Anne-Brit Kolst $\varnothing$ Otnæss, Laboratory of Gene Structure and Expression, National Institute for Medical Research, Ridgeway, Mill Hill, London NW 7 1AA, England.

This research was supported by the Diarrhoeal Diseases Control Programme of the World Health Organization, Nestlé Nutrition Research Foundation, The Norwegian Women's Public Health Association, and Norwegian Research Council for Science and the Humanities.
HPTLC, high performance thin-layer chromatography LT, Escherichia coli heat-labile enterotoxin mG, milk ganglioside PBS, phosphate-buffered saline

Breast-fed infants are less susceptible to gastrointestinal infections compared to infants fed on cow's milk or formula milk (13 ). The protective potential of human milk may have its greatest impact in areas with poor hygiene and high exposure rates. In such areas, it has been shown that breast-feeding significantly reduces infant morbidity and mortality associated with diarrheal diseases (4). However, it is also well documented that breast-fed infants in populations with higher living standards experience a lower rate of gastrointestinal illness than infants fed on cow's or formula milk (5). Several of the factors in human milk which are considered to be of importance in the protection of the infant against bacterial disease (6) are found in markedly lower quantities in bovine milk. This applies especially to secretory IgA, lactoferrin, lysozyme, and Lactobacillus bifidus growth factors (7).

In previous reports byOtnæss and coworkers $(8-10)$ it has been reported that nonimmunoglobulin fractions from human milk inhibit LT and CT. We have previously demonstrated that this enterotoxin-inhibitory activity resides in the milk ganglioside fraction (11).

Gangliosides are glycosphingolipids which contain sialic acid and are mainly found in cell membranes. The ganglioside GM1 is the cell membrane receptor for CT (12-14), as well as for LT $(15,16)$. An additional receptor, a glycoprotein, may exist for LT (17)

In milk, gangliosides are found mainly in the fat globule membranes $(18,19)$ which are derived from mammary gland cell membranes. In a study of bovine milk, six gangliosides were detected (19) of which three have been identified as GD3, GM2, and $\operatorname{GM} 3(19,20)$.

Preliminary studies indicated that bovine milk contained less enterotoxin-inhibitory activity than human milk $(21,22)$. One likely explanation is that this is caused by a difference in the ganglioside composition. The purpose of the present study was to compare the ganglioside fractions from human and bovine milk with respect to ganglioside composition and enterotoxininhibitory activity.

\section{MATERIALS AND METHODS}

Materials. Chloroform and methanol were of analytical grade (Merck, Darmstadt, W. Germany). Purified CT was obtained from List Biological Laboratories, Inc. (Campbell, CA). Purified GM1, GD1a, GT1b from bovine brain (Supelco Inc., Bellefonte, 
PA) and bovine brain gangliosides (type III, Sigma Chemical Company, St. Louis, MO) were used as commercial ganglioside standards.

Antisera. Rabbit anti-CT was prepared as described (9). Sheep anti-rabbit IgG was kindly provided by Dr. Terje Michaelsen, and $\left({ }^{125} \mathrm{I}\right)$ monoclonal anti-rabbit IgG by Dr. Otto Closs, both from the National Institute of Public Health, Oslo, Norway.

Milk samples. Human milk was obtained from the Milk Bank at Ullevål Hospital, Oslo. Equal amounts of milk from each of 10 healthy women $2-10$ months postpartum were pooled. Unprocessed bovine milk was obtained from lactating cows. Bovine milk-based formula milk (NAN, Société des Produits Nestlé S. A. Vevey, Switzerland) was prepared according to the instructions of the producer. The human and bovine milk samples were stored at $-20^{\circ} \mathrm{C}$

Milk fat was obtained by centrifugation (human milk: 35,000 $\times g, 20 \mathrm{~min}$; bovine milk: $15,000 \times g, 1 \mathrm{~h}$; formula milk: 9,400 $\left.\times g, 2 \mathrm{~h} ; 4^{\circ} \mathrm{C}\right)$. The fat yield from human milk was $62 \mathrm{~g} /$ liter wet weight. From bovine and formula milk 60 and $50 \mathrm{~g}$ milk fat/liter, respectively, were obtained.

Ganglioside isolation and analysis. The milk fat was extracted with 19 vol chloroform/methanol/water (4:8:3) (23) as described (11) and a crude ganglioside preparation was obtained by solvent partition, protein precipitation and dialysis according to Svennerholm and Fredman (23). Milk gangliosides were dissolved by mild sonication in chloroform/methanol/water $(65: 25: 1)$ for HPTLC analysis, or in PBS for ELISA and rabbit small bowel loop assay.

HPTLC was performed using silica gel $60 \mathrm{HPTLC}$ precoated plates (glassplates $10 \times 10 \mathrm{~cm}$, or aluminum sheets; Merck). The plates were activated at $100^{\circ} \mathrm{C}$ and developed in chloroform/ methanol $/ 0.25 \% \mathrm{CaCl}_{2}$ in water $(60: 35: 8)$. For visualization of components, the plates were sprayed with resorcinol (24) or $\alpha$ naphtol/sulfuric acid (25) and incubated at $100^{\circ} \mathrm{C}$ for color development. Plates sprayed with resorcinol were covered with a clean glassplate during heating. Densitometry of HPTLC-plates was performed with a Shimadzu Dual-Wavelength TLC-Scanner CS-930. The chromatograms were obtained by single wavelength zig-zag scanning of each HPTLC-lane at $580 \mathrm{~nm}$ (beam dimension: $0.4 \times 0.4 \mathrm{~mm}$ ) in the reflection mode.

Small amounts of GM1 were detected by use of an HPTLCimmunoassay (Kolst $\varnothing$ Otnæss AB, Lægreid A, manuscript in preparation). GM1 was visualized by the successive incubation of the aluminum sheet HPTLC-plate in aqueous solutions containing i) native, freshly diluted $\mathrm{CT}$, ii) rabbit anti-CT, and iii) $\left({ }^{125} \mathrm{I}\right)$ monoclonal anti-rabbit IgG followed by autoradiography. Amounts of less than $0.01 \mathrm{ng}(0.0065 \mathrm{pmol}) \mathrm{GM} 1$ could be detected by this method.

Measurement of enterotoxin-inhibitory activity. The enterotoxin-inhibitory activity of milk ganglioside preparations was assayed in vitro by an ELISA test measuring the reduction of binding of CT to polyvinyl microtiterplates (Dynatec Laboratories Ltd., Sussex, England) coated with GM1 (26). The ELISA was performed essentially as described previously (11), employing purified CT instead of LT. Briefly, the milk gangliosides, dissolved in PBS, were incubated with equal volumes of a CTsolution $(0.1 \mu \mathrm{g} / \mathrm{ml})$ before application to the microtiterplate. The microtiterplate was incubated $1 \mathrm{~h}$ at $37^{\circ} \mathrm{C}$, followed by the successive incubation with rabbit anti-CT and sheep anti-rabbit IgG conjugated to alkaline phosphatase (27). The amount of bound CT in each well was measured spectrophotometrically as color development of enzyme substrate. A standard curve for CT $(0.001-0.1 \mu \mathrm{g} / \mathrm{ml})$ mixed with equal volumes of PBS was included on each microtiterplate.

The in vivo enterotoxin-inhibitory activity was assayed in a rabbit small bowel loop assay (28) as described (11). CT with or without milk gangliosides in a total volume of $1 \mathrm{ml}$ was injected into each of 20-25 small bowel loops in New Zealand White male rabbits $(1.8-2.4 \mathrm{~kg})$ anaesthetized with pentobarbituratum
$(25-40 \mathrm{mg} / \mathrm{kg})$. The animals were sacrificed after $19-20 \mathrm{~h}$ and the volume and length of each loop were measured. In each animal, two dose-response curves were obtained for CT mixed with buffer. Milk ganglioside preparations were tested with three different CT concentrations each.

\section{RESULTS}

Composition of the milk fat ganglioside preparations. The main human milk gangliosides, hmGI, hmGII, and hmGIII (11), showed similar migration on HPTLC-plates as three of the bovine milk gangliosides (Fig. $1 A$ ). These bovine milk gangliosides were designated bmGI-III. Two additional gangliosides, designated bmGIV and bmGV, were detected in the preparations from bovine and formula milk fat (Fig. $1 A$ ).

The amounts of the individual milk gangliosides (Table 1) were calculated from densitometric measurements of two parallel HPTLC-experiments with reference to standard curves for GM1. The standard curves were obtained by the inclusion of purified GM1 $(0.05-3.0 \mu \mathrm{g})$ on each HPTLC-plate. Variation between the two HPTLC-plates was 10-20\%. The recovery of gangliosides in the crude ganglioside preparation after protein precipitation and dialysis was $50 \%$ (28a) and the data in Table 1 were corrected accordingly, i.e. the measured values have been multiplied by a factor of 2 in order to obtain values representative for whole milk.

While the ganglioside pattern in bovine and formula milk was very similar, the relative amounts of the milk gangliosides I, II, and III were entirely different in human and bovine milk (Fig. $1 B$ and Table 1). The total ganglioside content in human and bovine milk fat seemed to be equal, while considerably less quantities of gangliosides were found in formula milk (Table 1).

Although GM1 was not detectable by staining with resorcinol or $\alpha$ naphtol (Fig. $1 A$ and Fig. $2 B$ ), this ganglioside was demonstrated in the human, as well as in the bovine and formula, milk ganglioside preparations by an immunoassay of HPTLCplates (Fig. 2A). The amount of GM1 derived from $1 \mathrm{~g}$ of human milk fat was $0.1 \mu \mathrm{g}$ (mean value; range $0.07-1.5 \mu \mathrm{g}$ ) while the corresponding values for bovine and formula milk fat were 0.01 $\mu \mathrm{g}$ (mean value; range $0.005-0.015 \mu \mathrm{g}$ ) and less than $0.01 \mu \mathrm{g}$, respectively. These results were based on seven independent experiments.

Enterotoxin-inhibitory activity of the milk fat ganglioside preparations. In vitro, measured by ELISA, the human milk ganglioside preparations showed significantly higher inhibitory activity against $\mathrm{CT}$ than the ganglioside preparations from bovine and formula milk (Fig. 3). Human milk gangliosides from $0.5 \mathrm{~g}$ fat per $\mathrm{ml}$ resulted in $100 \%$ inhibition, and the enterotoxin-inhibitory activity was still close to $50 \%$ on 10 -fold dilution (Fig. 3 ). However, in the case of bovine or formula milk, gangliosides from $1 \mathrm{~g}$ milk fat per $\mathrm{ml}$ were necessary for $100 \%$ enterotoxininhibition (data not shown) and inhibitory activity was more quickly lost on dilution (Fig. 3).

Higher enterotoxin-inhibitory activity of human, as compared to bovine, milk gangliosides was also found in the in vivo assay. Whereas human milk gangliosides from $0.5 \mathrm{~g}$ fat prevented fluid accumulation in rabbit small bowel loops at all CT-concentrations tested, bovine and formula milk gangliosides from $0.5 \mathrm{~g}$ milk fat showed practically no enterotoxin-inhibitory activity (Fig. 4). Human milk gangliosides still showed high in vivo inhibitory activity when the amount was reduced to $0.1 \mathrm{~g}$ milk fat (Fig. $5 \mathrm{~A}$ ). Bovine milk gangliosides from $1.0 \mathrm{~g}$ milk fat had to be applied to achieve enterotoxin-inhibitory activity similar to human milk gangliosides from $0.1 \mathrm{~g}$ fat (Fig. $5 B$ ). Although each of the graphs in Figures $4,5 A$, and $5 B$ was based on data obtained from a single animal, similar differences between human and bovine milk gangliosides were found in the four animals tested. 


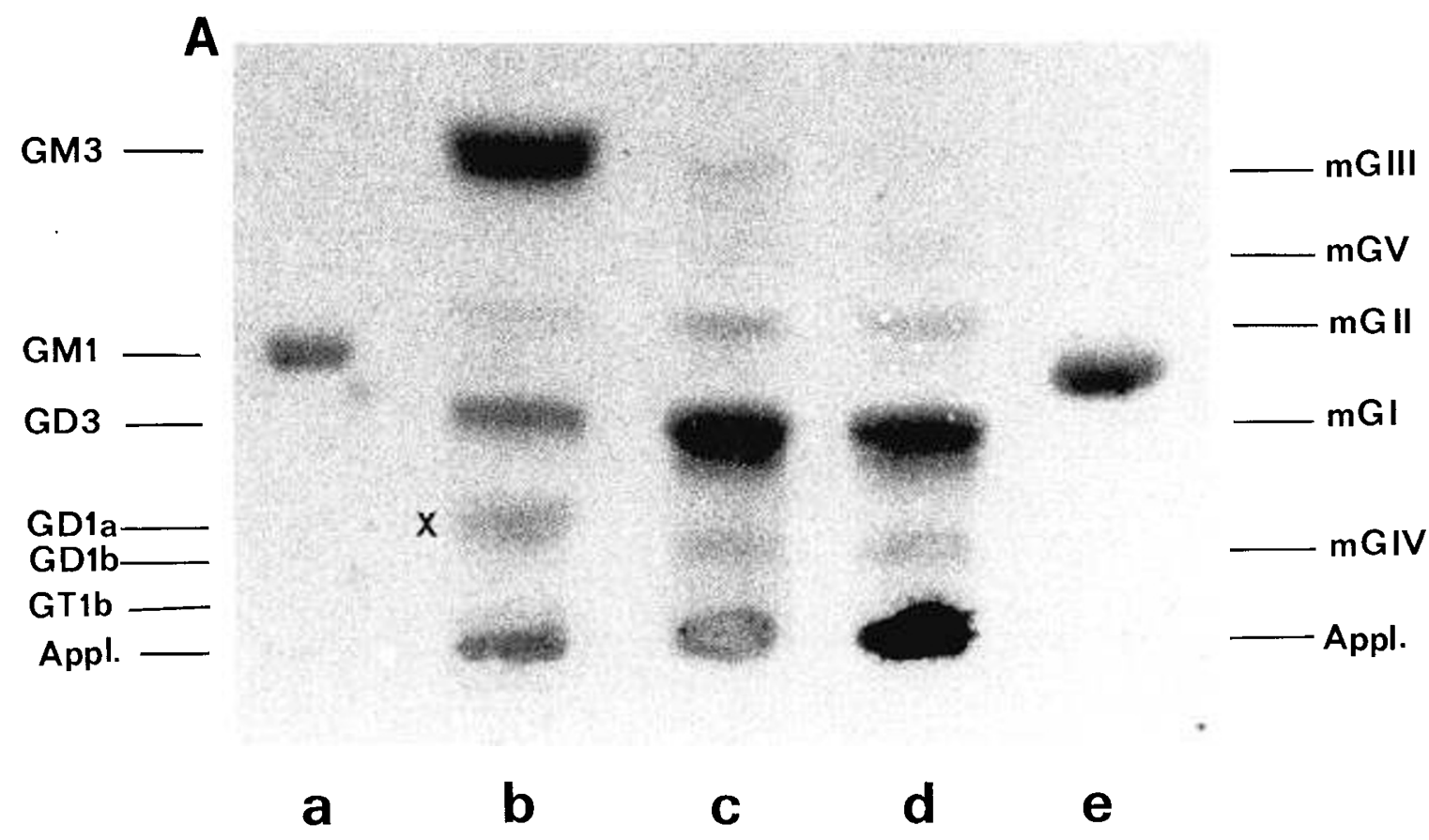

B
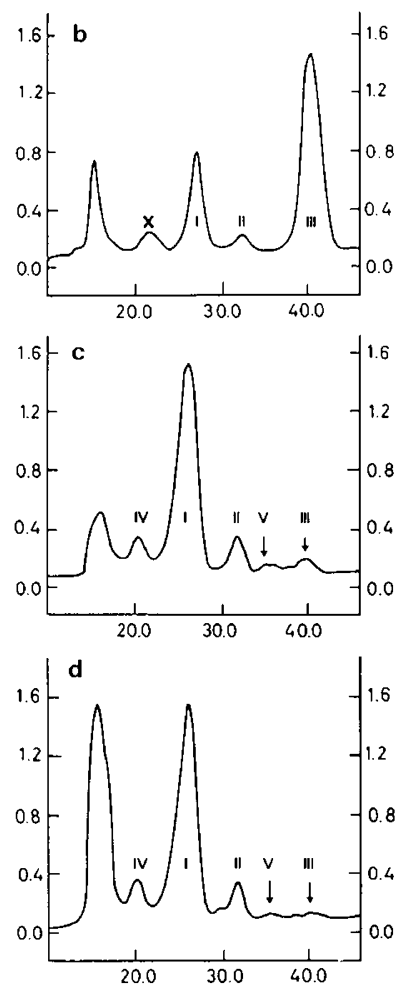

Fig. 1. A, resorcinol stained human, bovine and formula milk gangliosides after HPTLC. Lane $a, 1 \mu \mathrm{g} \mathrm{GMl}$; lane $b$, gangliosides from $0.1 \mathrm{~g}$ human milk fat; lane $c$, gangliosides from $0.1 \mathrm{~g}$ bovine milk fat; lane $d$, gangliosides from $0.14 \mathrm{~g}$ formula milk fat; lane $e, 3 \mu \mathrm{g}$ GM1. The sialic acidcontaining components yielding blue/purple spots were designated: human milk gangliosides, mGI-III; bovine and formula milk gangliosides, mGIV. Component $\mathrm{X}$ in human milk stained yellow with resorcinol and thus did not contain sialic acid. The migration of bovine brain gangliosides (type III, Sigma) and GM3 is indicated on the left side. Bands corresponding to bovine milk gangliosides II, III, and V are faint but were always clearly visible on the original plate and an identical pattern was reproduced in several experiments. $B$, densitometric tracing of lanes $b, c$, and $d$ shown in A. Abcissa: distance in mm from the lower edge of the HPTLC-plate. Ordinate: relative detector response. 


\section{DISCUSSION}

In the present study, it was shown that the relative amount of individual gangliosides in human milk fat differed markedly from that in bovine milk fat. Still, the total content of gangliosides was similar in human and bovine milk fat, and milk from the two species seemed to have several gangliosides in common. A comparison of the ganglioside pattern of human and bovine milk has not been previously published.

Ganglioside I from human and bovine milk (hmGI and bmGI) showed identical HPTLC-mobility with bovine brain GD3 (Fig. $1 A$ and Fig. $2 B$ ). GD3 has previously been identified as the most abundant ganglioside in bovine milk $(19,20)$, and our findings are in agreement with these data. Although preliminary gas chromatographic analysis of hmGI indicated that the sugar composition of hmGI was different from that of GD3 (29), further studies, using highly purified hmGI-preparations, showed that hmGI was identical with GD3 (Lægreid A, Kolst $\phi$ Otnæss A-B, Bryn X, manuscript submitted). The human milk ganglioside hmGIII is identical with GM3 (29; Lægreid A, Kolst $\varnothing$ Otnæss AB, Bryn X, manuscript submitted). Since the bovine milk ganglioside bmGIII migrated similarly to hmGIII (GM3) on HPTLC, it is likely that bmGIII was GM3 which has also been identified in bovine milk $(19,20)$. The milk gangliosides hmGII and bmGII migrated in the area of GM2 and may both be identical with GM2 known to be present in bovine milk $(19,20)$.

Table 1. Gangliosides in fat from human, bovine, and formula milk

\begin{tabular}{lcccccc}
\hline Gangli- & \multicolumn{2}{c}{ Human milk } & \multicolumn{2}{c}{ Bovine milk } & \multicolumn{3}{c}{ Formula milk } \\
oside* & $(\mathrm{mg} / \mathrm{liter})$ & $(\%)$ & $(\mathrm{mg} /$ liter $)$ & $(\%)$ & $(\mathrm{mg} / \mathrm{liter})$ & \multicolumn{1}{c}{$(\%)$} \\
\hline mGI & 2.7 & $(25)$ & 8.8 & $(80)$ & 4.9 & $(82)$ \\
mGII & 0.25 & $(2)$ & 0.7 & $(6)$ & 0.4 & $(7)$ \\
mGIII & 8.1 & $(74)$ & 0.3 & $(3)$ & $<0.05$ & $(<1)$ \\
mGIV & & & 1.2 & $(11)$ & 0.7 & $(12)$ \\
mGV & & & $<0.1$ & $(<1)$ & $<0.05$ & $(<1)$ \\
GM1 & 0.012 & $(0.1)$ & 0.0012 & $(0.01)$ & $<0.001$ & $(<0.01)$ \\
& & & & & & \\
Total & 11 & & 11 & & 6 & \\
\hline
\end{tabular}

* mGI-mGV were calculated from densitometric measurements of HPTLC-plates stained with resorcinol. GM1 was calculated from immunoassay of HPTLC-plates.
Trace amounts of GM1 were demonstrated in human, as well as in bovine, milk. The presence of GM1 in human milk has not previously been reported, and due to its low abundancy GM1 was not detected in an earlier study of bovine milk gangliosides (19). GM1 was identified by i) the binding of CT, a ligand which is highly specific for GM1 (30) and by ii) the identical HPTLCmobility of the CT-binding milk ganglioside with that of purified bovine brain GM1 (Fig. 2). Since the relative amounts of GM1 were $0.1 \%$ of the total human milk gangliosides and $0.01 \%$ of the bovine milk gangliosides, the detection of GM1 on thin-layer

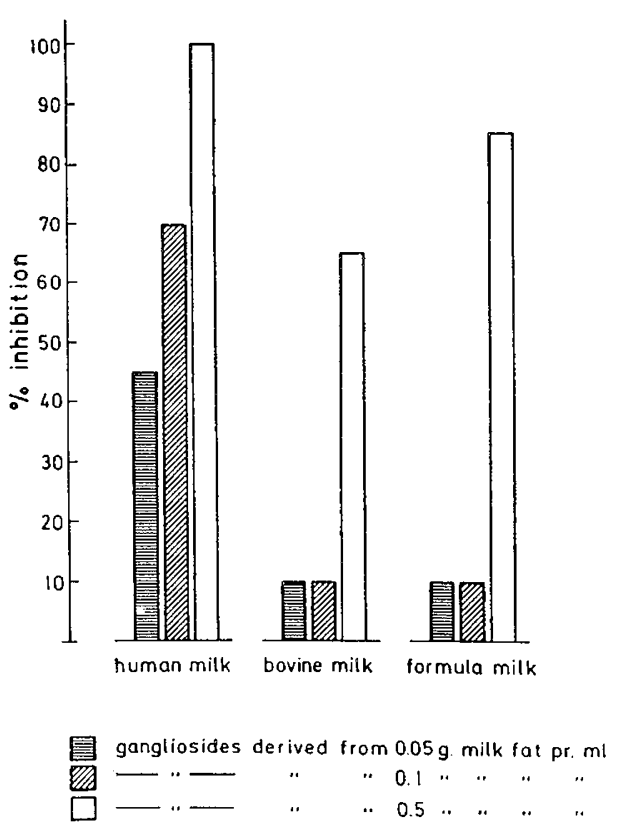

Fig. 3. Enterotoxin-inhibitory activity of human, bovine, and formula milk gangliosides measured in ELISA as the reduction of binding of CT to GM1-coated microtiter-plates. Values are means of four independent experiments, and each sample was tested in duplicate. SE was within 5-10\%; for human milk gangliosides at $0.5 \mathrm{~g}$ milk fat per $\mathrm{ml} \mathrm{SE}$ was less than $1 \%$. Differences between human milk and bovine and formula milk gangliosides are statistically significant by the $t$ test $(p<$ $0.001)$.
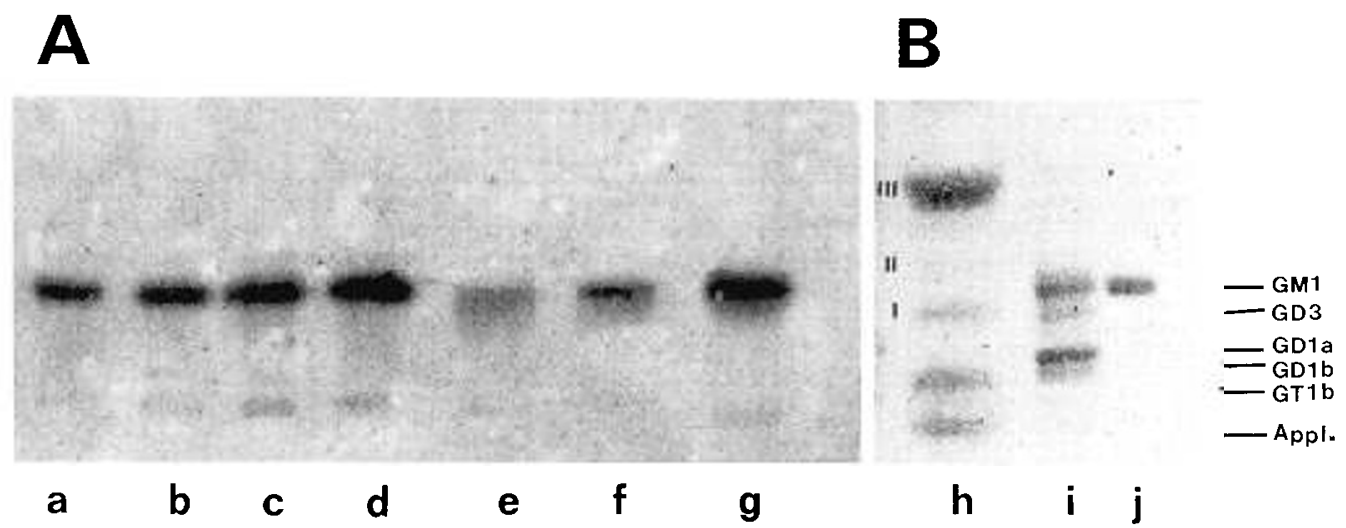

Fig. 2. HPTLC-analysis of human, bovine, and formula milk gangliosides. After chromatography, the HPTLC-plate (alu-sheet) was cut into two parts and gangliosides were visualized by: $A$, immunoassay and autoradiography (see "Methods and materials"); or $B, \alpha$-naphtol staining. Lane $a$, $0.1 \mathrm{ng} \mathrm{GM} 1$; lane $b, 0.5 \mathrm{ng}$ GM1; lane $c, 1.0 \mathrm{ng} \mathrm{GM1;} \mathrm{lane} d, 10.0 \mathrm{ng}$ GM1; lane e, formula milk gangliosides; lane $f$, bovine milk gangliosides; lane $g$, human milk gangliosides ( $e, f$, and $g$ : gangliosides from $0.01 \mathrm{~g}$ milk fat); lane $h$, human milk gangliosides (from $0.1 \mathrm{~g}$ milk fat); lane $i$, bovine brain gangliosides $(10 \mu \mathrm{g})$; lane $j$, GM1 $(2 \mu \mathrm{g})$. 
chromatograms was only possible by radioimmunological visualization of GM1-bound CT. By this method, the sensitivity was increased more than 1000 -fold compared to resorcinol staining, with the concurrent advantage of high specificity for GM1.

Thus, the gangliosides found in both human and bovine milk were GD3, GM1, GM3, and possibly GM2. The gangliosides bmGIV and bmGV were detected in bovine milk only. While the most abundant ganglioside in human milk was GM3, representing $74 \%$ of total gangliosides, this ganglioside was only a minor component (3\%) of the bovine milk gangliosides (Table 1). GD3 amounted to $80 \%$ of total bovine milk gangliosides compared to $25 \%$ of human milk gangliosides (Table 1). After completion of this work, Hauttecoeur et al. (31) published an analysis of GD3 from bovine buttermilk. GD3 represented $85 \%$ of total lipid-bound sialic acid in buttermilk which is in agreement with our data. The milk ganglioside, designated mGII (which may be GM2), was a minor ganglioside component in both human and bovine milk, representing 2 and $6 \%$, respectively, of total milk gangliosides (Table 1). The composition of formula milk gangliosides, on which no analysis has been reported earlier, appeared identical with the unprocessed bovine milk gangliosides except for the lower quantities of bmGIII in formula milk (Fig. $1 B$ and Table 1). The fact that such high correlation was found between the ganglioside patterns of two different preparations of bovine milk, i.e. fresh bovine milk and bovine milk-based formula milk, emphasizes the significance of

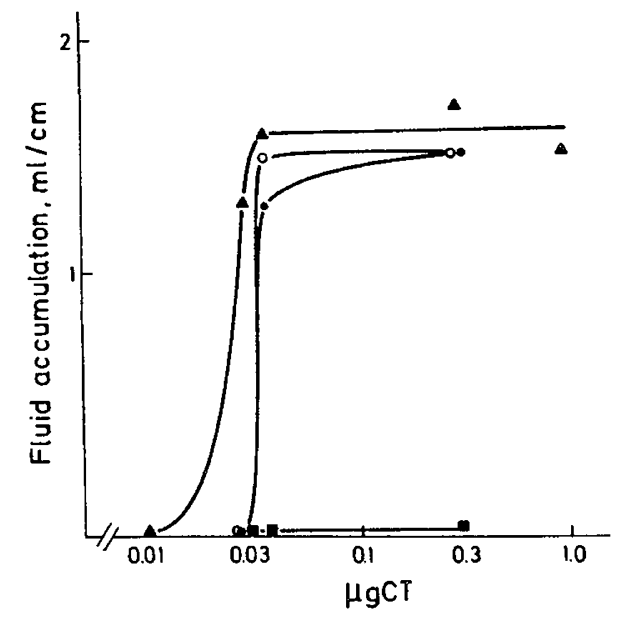

Fig. 4. Effect of human, bovine, and formula milk gangliosides on $\mathrm{CT}$-induced fluid accumulation in rabbit small bowel loop assay. $\mathbf{A T}$ + PBS, control; CT + gangliosides from $0.5 \mathrm{~g}$ human milk fat; $\bullet \mathrm{CT}$ + gangliosides from $0.5 \mathrm{~g}$ bovine milk fat; $+\mathrm{CT}+$ gangliosides from 0.5 $\mathrm{g}$ formula milk fat. the differences between human and bovine milk ganglioside patterns observed in this study.

The present study extends our preliminary data on the difference between nonimmunoglobulin enterotoxin-inhibitory activity of human, compared to bovine and formula, milk (22). Human milk gangliosides from $0.1 \mathrm{~g}$ fat, corresponding to 0.8 ml whole milk, inhibited $70 \%$ of the binding of $0.1 \mu \mathrm{g}$ CT in vitro, while the same amount of gangliosides completely inhibited fluid accumulation in rabbit ileal loops induced by $0.1 \mu \mathrm{g} \mathrm{CT}$. These results are in agreement with data obtained by measurements of the enterotoxin-inhibitory activity of gangliosides from a different pool of human milk in a previous study (11). In comparison, five to 10 times higher amounts of bovine or formula milk gangliosides were necessary to achieve similar enterotoxin inhibition. The inhibitory activity in human milk gangliosides might be physiologically relevant since Vibrio cholerae in culture produces much less than $1 \mu \mathrm{g}$ CT per ml (32), and the concentration of CT in stools from cholera patients has been reported to be in the range of from less than 0.001 to 0.15 $\mu \mathrm{g} / \mathrm{ml}(33)$.

Similar to a previous study (11), there was good agreement between enterotoxin-inhibitory activities measured in vivo in rabbit intestines and in vitro by the ELISA method as similar differences between the human and bovine milk gangliosides preparations were found by both methods.

In a previous study, the enterotoxin-inhibitory activity of the human milk ganglioside preparation was eluted from TLC in an area where GMl and hmGI migrated (11). Since by HPTLC no GM1 was detected in a preparation of $\mathrm{hmGI}$, although considerable toxin-inhibitory activity was measured (29), we concluded that the toxin-inhibitory was most likely due to hmGI rather than GM1. However, when the 1000-fold more sensitive HPTLC-immunoassay for GM1 was employed, GM1 was detected in the hmGI-preparation (Lægreid A, Kolst $\varnothing$ Otnæss A-B, manuscript in preparation). Upon separation of human milk gangliosides, the inhibitory activity was found only in fractions which contained GM1 while highly purified preparations of hmGI and hmGIII which were devoid of GM1 showed no enterotoxin-inhibitory activity (Lægreid A, Kolst $\phi$ Otnæss A-B, manuscript in preparation).

Thus the trace amounts of GM1 present in human, as well as in bovine, milk were most likely responsible for the enterotoxininhibitory activity in the ganglioside fractions. Compared to human milk gangliosides, five to 10 times more of the bovine milk gangliosides had to be applied to achieve a similar inhibition of CT. This correlated well with the finding of one-tenth the amount of GM1 in bovine milk fat compared to human milk fat.

The inhibitory activity against LT was not measured in this study. However, earlier studies have shown that LT and CT are inhibited to a similar extent by nonimmunoglobulin human
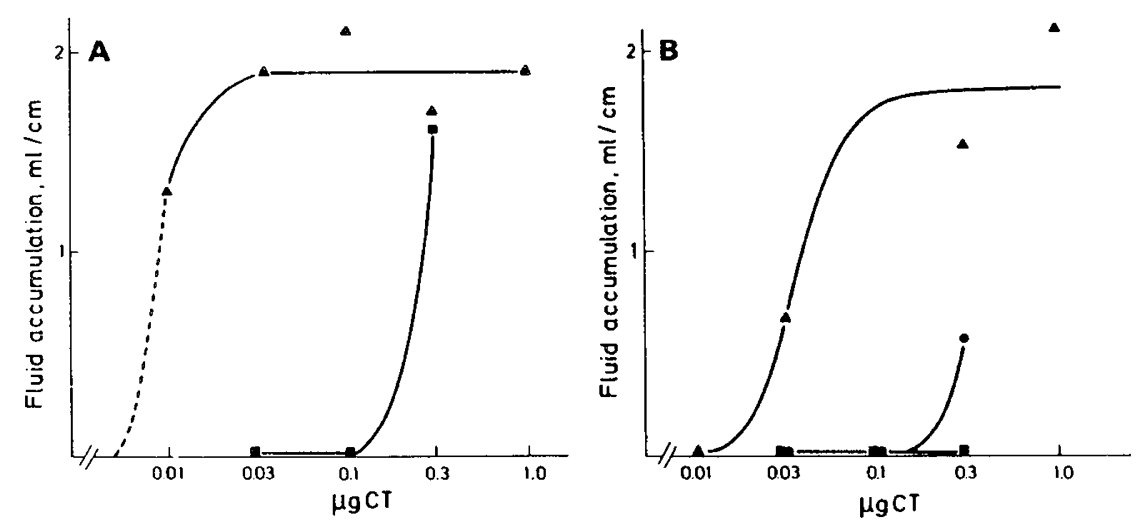

Fig. 5. Effect of human and bovine milk gangliosides on CT-induced fluid accumulation in rabbit small bowel loop assay. $A$, gangliosides from $0.1 \mathrm{~g}$ human milk fat; $B$, gangliosides from $1.0 \mathrm{~g}$ human or bovine milk fat. $\Delta \mathrm{CT}+\mathrm{PBS}$, control; $\mathrm{CT}+$ human milk gangliosides; $\bullet \mathrm{CT} \pm$ bovine milk gangliosides. 
milk fractions $(10,11)$. In addition to GM1, which probably prevents binding of enterotoxins to intestinal cells, human milk may contain receptor-like glycocompounds which can prevent adherence of $V$. cholerae and Escherichia coli $(34,35)$.

The presence in human milk of secretory IgA against $V$. cholerae and $E$. coli enterotoxins (36) and against bacterial membrane antigens $(37,38)$ most likely plays the most important role in the protection of infants against diarrhea following bacterial infection, as suggested by a field study in a cholera endemic area (38). The antidiarrheal potential of human milk has also been demonstrated by the interruption of $E$. coli diarrhea with small quantities of human colostrum $(5 \mathrm{ml} / \mathrm{kg} / \mathrm{day})(39)$, as well as by the successful treatment of protracted diarrhea by feeding affected infants with mature milk (40).

The demonstration that GM1 is a nonimmunoglobulin component contributing to the enterotoxin-inhibitory activity of human milk (Lægreid A, Kolst $\varnothing$ Otnæss A-B, manuscript in preparation) indicates that compounds present in trace amounts only may play a significant role in the "second line of defense" against infection when a high level of specific antibodies is lacking. The present study shows that bovine and formula milk contain significantly lower levels of GM1 compared to human milk and that the lower levels of GM1 are associated with markedly lower enterotoxin-inhibitory activity in bovine and formula milk.

Acknowledgments. The authors thank Anne-Marie Berger and Per Solberg for excellent technical assistance and Liss Fusdahl and Tove Brit Nøland for typing this manuscript.

\section{REFERENCES}

1. Gerrard JW 1974 Breast-feeding: Second thoughts. Pediatrics 54:757-764

2. Larsen SA 1978 Relation of breast versus bottle feeding to hospitalization for gastroenteritis in a middle-class U.S. population. J Pediatr 92:417-418

3. Svirsky-Gross S 1958 Pathogenic strains of Coli (0.111) among prematures and the use of human milk in controlling the outbreak of diarrhoea. Ann Paediat 190:109-115

4. Jason JM, Nieburg P, Marks JS 1984 Mortality and infectious disease associated with infant-feeding practices in developing countries. Pediatrics 74(suppl):702-727

5. Kovar MG, Serdula MK, Marks JS, Fraser DW 1984 Review of the epidemiologic evidence for an association between infant feeding and infant health. Pediatrics 74(suppl):615-638

6. Welsh JK, May JT 1979 Anti-infective properties of breast milk. J Pediat 94:1-9

7. Blanc B 1981 Biochemical aspects of human milk-comparison with bovine milk. Wld Rev Nutr Diet 36:1-89

8. Otnæss A-B, Halvorsen S 1980 Non-antibody components in human milk inhibit Escherichia coli heat-labile enterotoxin measured by an enzymelinked immunosorbent assay. Acta Path Microbiol Scand Sect C 88:247253

9. Otnæss A-BK, Ørstavik I 1981 Effect of fractions of Ethiopian and Norwegian colostrum on rotavirus and Escherichia coli heat labile enterotoxin. Infect Immun 33:459-466

10. Otnæss A-B, Svennerholm A-M 1982 Non-immunoglobulin fraction of human milk protects rabbits against enterotoxin-induced intestinal fluid secretion Infect Immun 35:738-740

11. Kolst $\varnothing$ Otnæss A-B, Lægreid A, Ertresvåg K 1983 Inhibition of enterotoxin from Escherichia coli and Vibrio cholerae by gangliosides from human milk. Infect Immun 40:563-569

12. Cuatrecasas $\mathbf{P} 1973$ Interaction of Vibrio cholerae enterotoxin with cell membranes. Biochemistry 12:3547-3558

13. Holmgren J, Lönnroth I Svennerholm L 1973 Tissue receptor for cholera exotoxin: Postulated structure from studies with GM1 ganglioside and related glycolipids. Infect Immun 8:208-214

14. King CA, van Heyningen WE 1973 Deactivation of cholera toxin by sialidaseresistant monosialosylganglioside. J Infect Disease 127:639-647

15. Donta ST, Viner JP 1975 Inhibition of the steroidogenic effects of cholera and heat-labile Escherichia coli enterotoxins by GM1 ganglioside: evidence for a similar receptor site for the two toxins. Infect Immun 11:982-985

16. Zenser TV, Metzger JF 1974 Comparison of the action of Escherichia coli enterotoxin on the thymocyte adenylate cyclase-cyclic adenosine monophosphate system to that of cholera toxin and prostaglandin $E_{1}$. Infect Immun 10:503-509

17. Holmgren J, Fredman P, Lindblad M, Svennerholm A-M, Svennerholm L 1982 Rabbit intestinal glycoprotein receptor for Escherichia coli heat-labile enterotoxin lacking affinity for cholera toxin. Infect Immun 38:424-433

18. Grimmonprez L, Montreuil J 1977 Étude des fractions glycanniques des glycosphingolipids totaux de la membrane des globules lipidiques du lait de femme. Biochimie 59:899-907

19. Keenan TW 1974 Composition and synthesis of gangliosides in mammary gland and milk of the bovine. Biochim Biophys Acta 337:255-270

20. Huang RTC 1973 Isolation and characterization of the gangliosides of butter milk. Biochim Biophys Acta 306:82-84

21. Kolst $\phi$ Otnæss A-B, Lægreid A 1984 The study of a GM1-like inhibitor in milk of enterotoxins from Escherichia coli and Vibrio cholerae. In: Alouf JE (ed) Bacterial Proteins Toxins. FEMS Symposia Series, Academic Press, London, pp 367-368

22. Kolst $\varnothing$ Otnæss A-B, Lægreid A, Ørstavik I, Trollerud K 1984 Studies on nonimmunoglobulin inhibitory activity in human milk against $E$ coli heat labile enterotoxin, rotavirus and respiratory syncytical virus. In: Williams AF, Baum JD (eds) Human Milk Banking. Nestlé Nutrition, Vevey/Raven Press, New York, pp 85-92

23. Svennerholm L, Fredman P 1980 A procedure for the quantitative isolation of brain gangliosides. Biochim Biophys Acta 61 7:97-109

24. Svennerholm L 1957 Quantitative estimation of sialic acids II A colorimetric resorcinol-hydrochloric acid method. Biochim Biophys Acta 24:604-611

25. Siakotos AN, Rouser G 1965 Analytical separation of nonlipid water soluble substances and gangliosides from other lipids by dextran gel column chromatography. J Am Oil Chem Soc 42:913-919

26. Svennerholm A-M, Holmgren J 1978 Identification of Escherichia coli heatlabile enterotoxin by means of a ganglioside immunosorbent assay (GM1ELISA). Curr Microbiol 1:19-23

27. Voller A, Bidwell D, Bartlett A 1976 Microplate enzyme immunoassays for the immunodiagnosis of virus infections. In: Rose NR, Friedman $\mathrm{H}$ (eds) Manual of Clinical Immunology. American Society for Microbiology, Washington, DC, pp 506-512

28. Svennerholm A-M 1975 Experimental studies on cholera immunization. IV The antibody response to formalinized $V$. cholera and purified endotoxin with special reference to protective capacity. Int Arch Allerg Appl Immuno 49:434-452

28a. Lægreid A, Kolstø Otnæss A-B, Bryn K 1986 Purification of human milk gangliosides by silica gel chromatography and analysis of trifluoroacetate derivatives by gas chromatography. $\mathbf{J}$ Chromatogr (in press)

29. Lægreid A, Otnæss A-BK 1985 The identification of a human milk ganglioside which inhibits $E$. coli and V. cholerae enterotoxins. In: Peeters H (ed) Protides of the biological fluids. Proc of the 32nd Coll, Pergamon Press Ltd, Oxford, pp 231-234

30. Fishman PH 1982 Role of membrane gangliosides in the binding and action of bacterial toxins. J Membr Biol 69:85-97

31. Hauttecoeur B, Sonnino S, Ghidoni R 1985 Characterization of two molecular species GD3 ganglioside from bovine buttermilk. Biochim Biophys Acta 833:303-307

32. Holmgren J 1981 Actions of cholera toxin and the prevention and treatment of cholera. Nature 292:413-417

33. Stoll BJ, Holmgren J, Bardhan PK, Huq I, Greenough III WB, Fredman P, Svennerholm L 1980 Binding of intrahuminal toxin in cholera: Trial of GM1 ganglioside charchoal. Lancet 2:888-891

34. Holmgren J, Svennerholm A-M, Ảhren C 1981 Nonimmunoglobulin fraction of human milk inhibits bacterial adhesion (hemagglutination) and enterotoxin binding of Escherichia coli and Vibrio cholerae. Infect Immun 33:136141

35. Holmgren J, Svennerholm A-M, Lindblad M 1983 Receptor-like glycocompounds in human milk that inhibit classial and El Tor Vibrio cholerae cell adherence (hemagglutination). Infect Immun 39:147-154

36. Stoliar OA, Pelley RP, Kaniecki-Green E, Klaus MH, Carpenter CCJ 1976 Secretory IgA against enterotoxins in breast milk. Lancet 1:1258-1261

37. Dolby JM, Stephens S 1983 Antibodies to Escherichia coli 0 antigens and the in-vitro bacteriostatic properties of human milk and its IgA. Acta Paediatr Scand 72:577-582

38. Glass RI, Svennerholm A-M, Stoll BJ, Khan MR, Hossain KMB, Huq MI, Holmgren J 1983 Protection against cholera in breast-fed children by antibodies in breast milk. N Engl J Med 308:1389-1392

39. Larguia AM, Urman J, Ceriani JM, O'Donnel A, Stoliar OA, Martinez JC, Buscaglia JC, Weils S, Quiroga A, Irazu M 1974 Immunidad local en el recién nacido. Primera experiencia con la administracion de calostro humano a recién nacidos pretérmino. Arch Argent Pediatr 72:109

40. MacFarlaine PI, Miller V 1984 Human milk in the management of protracted diarrhoea of infancy. Arch Dis Child 59:260-265

41. Svennerholm L 1963 Chromatographic separation of human brain gangliosides. J Neurochem 10:613-623

\section{APPENDIX}

(41).

The ganglioside nomenclature was according to Svennerholm

$G M 1$, galactosyl ( $\beta 1-3) \mathrm{N}$-acetylgalactosaminyl $(\beta 1-4)$ (neuraminyl $\alpha 2-3)$ galactosyl $(\beta 1-4)$ glycosyl $(\beta 1-1)$ ceramide.

$G M 2$, N-acetylgalactosaminyl ( $\beta$ 1-4) (neuraminyl $\alpha$ 2-3) galactosyl $(\beta 1-4)$ glycosyl $(\beta 1-1)$ ceramide.

$G M 3$, neuraminyl ( $\alpha 2-3)$ galactosyl $(\beta 1-4)$ glycosyl $(\beta 1-1)$ ceramide.

$G D 3$, neuraminyl ( $\alpha 2-8)$ neuraminyl ( $\alpha 2-3)$ galactosyl $(\beta 1-4)$ glycosyl ( $\beta 1-1)$ ceramide. 